\title{
Vilma-Irén Mihály, Levente Pap, Judit Pieldner, Zsuzsa Tapodi, eds. Homo viator. Studies on Literature, Linguistics and Culture.
}

\author{
Bucharest, Sfântu Gheorghe, Cluj-Napoca: RHT, \\ Transylvanian Museum Society, 2015.
}

\author{
Review by \\ András ZOPUS \\ University of Nyíregyháza (Nyíregyháza, Hungary) \\ Institute of Linguistics and Literature \\ drsza@yahoo.com
}

In order to reach an external position, that of the spectator, travel is required: it enables us to withdraw, thus providing us with an opportunity to step out of apathy and the circumstances we are bored with. Travel is a particular way of solution ensuring us to be in control of situations determined by curiosity, desires and possibilities. The volume of the 2015 international conference Homo viator, organized by the Department of Humanities, Sapientia University, Miercurea Ciuc, Romania, the Society of Hungarology from Romania and the Romanian Association of General and Comparative Literature, comprises the written versions of Hungarian-language presentations held on the occasion of the multidisciplinary conference. The presentations, eighty altogether, were held in Hungarian, Romanian, and English. The editors have selected two plenary presentations and twenty-eight studies into the volume, grouping the latter ones into five chapters.

The volume begins with the studies written by the keynote speakers. On the basis of various works from Hungarian and world literature, István Fried examines the experience of travel defined by literary periods and the travellers' personalities. Based on several English, German, and Russian works quoted as examples, he also explains the peculiar imagological motifs reflected in Sándor Petôfi's and János Arany's poems. Through his analysis of a Prešeren-sonnet in the appendix, Fried reveals that the poetic travel/traveller might fail to achieve its goal. In her paper Mihaela Albu gives us some insight into getting to know ourselves and the world beyond by means of travel, elucidating all the knowledge required for 
seeing life and gaining maturity as present in the context of folk tales. The first part of the study consisting of three parts is centred on the disillusioned Homo viator, fleeing from reality; the second, on the experience of the well-travelled man; and finally, the third, on the travelogue of those Romanian intellectuals who have been forced into exile by the regime.

In the chapter entitled "Towards a Community of Experience" Emese Egyed writes about the eighteenth century Hungarian poetic (travel) letters especially written by noble ladies, reflecting, among others, the contemporary life of the Transylvanian nobility. It was the organizers' explicit intention to commemorate the $220^{\text {th }}$ anniversary of Sándor Bölöni Farkas's birth on the occasion of the conference; Beáta Sikó's and Judit Erdély's detailed and illustrious works are directly relevant in this respect. Beáta Sikó closely scrutinizes the traces of Lafayette's cult and the impact of Levasseur's travelogue in Sándor Bölöni Farkas's work. She also draws attention to the way in which the account on Lafayette's farewell tour influenced the conception and themes of Journey in North America. Judit Erdély's work aims to analyse Sándor Bölöni Farkas's work in terms of language, stylistics and genre, and to introduce us into its linguistic context. Adél Csata, examining the image of nation in Ferenc Verseghy's Almarék erdélyi herczeg, avvagy a szebeni erdô [Almerich, Prince of Transylvania], points out that the translator integrates the images of the Romanians created in various eras, therefore Verseghy's novel translation depicts a landscape of stereotypical images. The configuration of the travel motifs in the poetic novels is analysed by Lenke Kocsis, who comes to the conclusion that there are no strictly genre-specific peculiarities in the topic. Orsolya-Petra Pavelka proposes to examine Miklós Jósika’s literary career in terms of history of mentality and society, thus applying two non-fictional corpora of text as the cornerstones of her research. Edit Bakó assumes the task of studying the issues of nationality and national minority; she discloses these by means of presenting Gergely Moldován’s first volume.

The works belonging to the second chapter of the volume, entitled "Gaining Experience, Passing Memories," are related to intercultural experience and the dilemmas of cultural mediation. Regarding the chivalric or noble study trips that became common amongst the noblemen in Transylvania in the seventeenth century, Emese Rácz describes József Teleki and Ádám Teleki’s study trip for gaining experience abroad. On the basis of a fragmentary manuscript, Tímea Berki examines how Sámuel Brassai used to travel, verifying the role of music in his life. Szilárd Szilágyi leads the reader into Ignác Kúnos’s research expedition to Asia Minor in 1890. Kúnos is considered to be the discoverer of Turkish folkpoetry; in his paper, Szilágyi attempts to resolve the contradictions being so frequent between Kúnos's papers and letters. Ferenc Németh is present in the volume with a study on pleasure trips brought about by bourgeois vouge. $\mathrm{He}$ writes about a story of four friends' Easter pleasure trip, which was so successful 
that the participants founded the society of pleasure travellers. A travel cannot dispense with a good guide-book, the generic definition and function of which are explained by András Lukács; based on Maslow's hierarchy of needs, he gives a new definition for the guide-book.

Examining the images of otherness, the relation of the self and the foreign were also issues debated in the conference. We can read the relevant studies in the chapter "Familiarity and Alienation in Space and Time." Comparing Mór Jókai's Az arany ember [The Man with the Golden Touch] and Péter Esterházy's Hahn-Hahn grófnó pillantása [The Glance of Countess Hahn-Hahn], Diána Sóki aims to explore the novelistic roles, functions, and meanings of the Danube; Sóki examines the river as a text and a deposit of texts. Examining Miklós Mészöly's Pontos történetek, útközben [Exact Stories, On the Way], Lili Balogh discloses the general feeling of an age. In her work, the effect of the text on the reader is illustrated through the examination of narration. The spatial and temporal motifs of setting off, a frequent theme in Transylvanian lyrical poetry, are characterized with metafors of László Király’s pre-1990 poetry by Szilárd László Szilveszter. He examines the ways in which the various motifs of familiarity and foreignness appear due to the lack of freedom to travel, and how these motifs get related to metaphors and allegories of the road, roving life and pilgrimage in László Király's poetry. Flóra Kovács, analysing Zsófia Balla’s poem Vonatok [Trains], points out that the fields of travel, time, and metrical poetry are interrelated, and that the poetess makes the trip with an attachment to literary traditions. Space is the major trope of János Térey's oeuvre so far, states Ágnes Balajthy, who ascertains by means of the examination of strategies of spatial poetry in the author's work that the representation of space is closely related to that of the various kinds of travel experience in the texts. Analysing Terézia Mora's prose poetics, Éva Toldi comes to the conclusion that continuous movement, the layered and accumulating dynamism of space and the self-stratification of liveliness take place because the only thing happening in the novel is ceaseless change of place. While analysing Gergely Péterfy's novel Kitömött barbár [Stuffed Barbarian], Zsuzsa Tapodi states that it is travel that provides the plot of the novel with a frame and structuring principle. The journeys mainly have initiating, awakening, and self-reflexive functions in Richard Flanagan's novel The Narrow Road to the Deep North. In her reflections, Júlia Vallasek elucidates that the protagonists of the novel remain irrevocably in the state of travelling, against their wishes and due to what they have undergone, for they build a narrow path leading not to the geographical north, but to the inscrutable "northern realms" of human nature. Focusing on the cyborg phenomenon from a new aspect, Eszter Vidosa examines the travel commencing when someone goes beyond the boundaries of body and identity.

The chapter "Travelling between Cultures" includes studies on intercultural interaction, all of which are linked to Vojvodina. In her study Erika Bence 
explains the phenomenon of travelogues in the latest Hungarian literature from Vojvodina. Analysing the intercultural "time-space" of contemporary Hungarian short stories from Vojvodina, Gábor Crnkovity points out that travel takes place along two axes, horizontal and vertical, and the two-dimensional, mutually free access between them is provided by the history and context of short stories. Gabriella Lódi examines the tropes of road and journey in some contemporary short stories from Vojvodina, presenting the anecdotes and motifs of nostalgic travel, and she comes to the conclusion that the road does not leave the framework defined by the text, and finally, it returns to its starting point. Csapó Julianna Ispánovics analyses the role of bibliography in Vojvodinian Hungarian science and culture; she states that Vojvodinan bibliography - accomodating itself to the circumstances of minority position - has survived, and stands up in terms of both quantity and quality.

The final chapter of the volume of studies, entitled "Interaction between Cultures and Languages," contains linguistic studies. Based on the accepted view claiming that no literary interpretation may take place without taking the linguistic rendering of a work into consideration, Réka Pupp seeks the linguistic forms expressing the trope of travel in the literary text in question, Szindbád hazatér [Sindbad Returns Home] by Sándor Márai. Interpreters become real travellers among cultures, languages and customs, so they always need to be vigilant - this is Krisztina-Mária Sárosi-Márdirosz's conclusion. In her study she points out that interpretation does not deal with creating the equivalence of micro-contexts, but is aimed at establishing a much more complex equivalence, which, in an ideal case, will meet the expectations of the target-language audience. Analysing the types and roles of code-switching in the use of language among the Hungarian minority from Vojvodina, Ilona Rajsli draws the following conclusion: codeswitching may fill a long-felt gap, but may also express prestige, an attitude to language; it may have a style or register changing character; it may also express the speaker's solidarity with his or her group.

The thoroughness, richness in detail and high standard of the papers in the extensive, 419-page volume demonstrate the presenters' interest and mastery in the issue of Homo viator, which was the title of the conference and also of the volume of studies. In this way, the presentations facilitate a more profound understanding and exploration of this set of issues. The various natures of the roads are reflected through the multi-faceted features of the discussed and interpreted works, demonstrating that both external and internal journeys lead us to a new place, a distinct level of cognition. 